
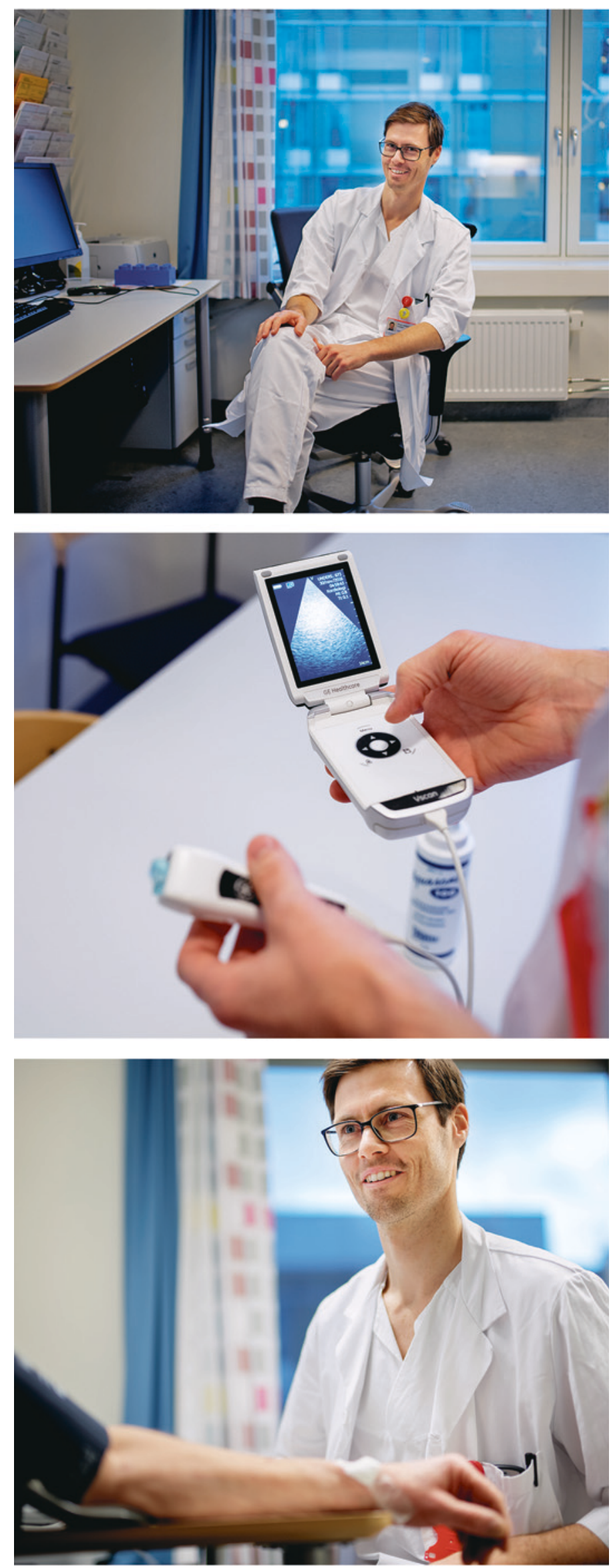

Foto: Ole Martin Wold/NTB Scanpix

\section{Nyresvikt, hypertensjon og optimalt blodtrykksmål}

\author{
Knut Asbjørn Rise Langlo er ph.d.-student i indre-
} medisin og lege i spesialisering i nyremedisin ved medisinsk klinikk ved St. Olavs hospital i Trondheim.

\section{Skjer det noko interessant innan fagfeltet ditt for tida?}

Behandlingsmål for pasientar med hypertensjon er mykje diskutert siste året, etter at SPRINT-studien viste redusert førekomst av kardiovaskulær sjukdom og død ved meir aggressiv behandling, og at dette også gjeld for eldre. SPRINT-studien viste at behandling med mål systolisk blodtrykk $120 \mathrm{~mm} \mathrm{Hg}$ gav betre resultat og få komplikasjonar. Dette reiser igjen debatten om kva som er det optimale blodtrykksmålet.

Ny behandling for pasientar med autosomalt dominant cystenyresjukdom er også ei stor nyheit. Tolvaptan er den første behandlinga for tilstanden som kvart år er årsak til $7 \%$ av nye pasientar i endestadium nyresvikt i Noreg. Medikamentet bremsar progredieringa og kan utsetje behovet for dialyse eller transplantasjon.

\section{Vil du tilrå ein ny og spanande artikkel?}

Ein veldig spanande diskusjon å følgje med på er antikoagulasjon for atrieflimmer hos dialysepasientar. Store randomiserte studiar har vist nytten av antikoagulasjon for å førebygge embolisk hjerneslag hos nyrefriske, mens ein berre har observasjonsdata eller subpopulasjonsanalyser frå større studiar på nyresjuke. Dialysepasientar har paradoksalt nok både auka blødingsrisiko og tromboserisiko. Her er data sprikande. Marevan har fleire biverknader hos dialysepasientar, slik som auka kalsifisering av arteriar. Det er også aukande førekomst av kalsifylaksi. Nye perorale antikoagulasjonsmedikament (NOAK) er generelt ikkje godkjende for dialysepasientar. Derfor er eg svært einig med konklusjonen i denne oversiktsartikkelen - at det trengs randomiserte studiar på dialysepasientar med atrieflimmer (1).

\section{Kva er ditt favoritthjelpemiddel på jobb?}

Handhaldt ultralyd. Sengeposten vår har mange pasientar med kronisk nyresvikt og tilleggssjukdom som infeksjonar og hjartesjukdom. Det gjer at volumvurderingar ved hjelp av vitalparametere, urinproduksjon, kliniske teikn og vekt er ein viktig del av kvardagen. Tilgang på $V$-skann på sengeposten er eit svært nyttig tilskot, og er ofte utslagsgivande for konklusjon om væskestatus. Ofte utførast denne som vanleg ultralyd av hjarte med måling av vena cava-diameter, men eg forsøker også å lære meg å vurdere lungestuvning. I tillegg er ultralyd nyttig til å vurdere avløpshinder i nyrene og perikardvæske. På hemodialyseavdelinga har vi også probe til vurdering av dialysefistlar. Dette gir supplement i vedtaksprosessen, og gjer nok ofte at avgjerda kjem raskare.

\section{Anbefalt litteratur}

1. Gill S, Jun M, Ravani P. Atrial fibrillation and chronic kidney disease: struggling through thick and thin. Nephrol Dial Transplant 2016; E-publisert 14.10.2016.

Har du tips til personar vi kan intervjue? Ta kontakt med lisa.dahlbak.jacobsen@tidsskriftet.no 